\title{
Studi Analisis Pengaruh Perubahan Posisi Nozzle Terhadap Pout Pada Prototipe PLTMH
}

\author{
K. Daniel Kristama Vika ${ }^{1}$, Antonius Ibi Weiking ${ }^{2}$, Lie Jasa ${ }^{3}$
}

\begin{abstract}
Renewable sources of energy by utilizing water resources, more specifically is PLTMH (Micro-Hydro power plants) to be an excellent choice for potential to be developed in order to overcome the scarcity of energy. For ease in learning about PLTMH then use PLTMH prototype by designing the nozzle position on the corner of $0^{\circ}, 15^{\circ}, 30^{\circ}, 45^{\circ}, 60^{\circ}$ and $75^{\circ}$ to measurements, using three types of turbine vanes, on the position of the nozzle at an angle of $60^{\circ}$ produces round generator and turbine rotation. The position of the nozzle at an angle of $60^{\circ}$, a model turbine vanes are recommended to be used is semicircular vanes model because the model in the position and the powergenerating turbine vanes most large.

Intisari-Sumber energi terbarukan dengan memanfaatkan sumber daya air, lebih khusus lagi adalah PLTMH (Pembangkit Tenaga Mikro Hidro) menjadi pilihan yang sangat potensial untuk dikembangkan guna mengatasi kelangkaan energi. Untuk mempermudah dalam melakukan pembelajaran mengenai PLTMH maka digunakan prototipe PLTMH dalam penelitian ini, dengan mendesain posisi nozzle di sudut $0^{\circ}, 15^{\circ}, 30^{0}, 45^{\circ}, 60^{\circ}$ dan $75^{\circ}$ untuk setiap pengukuran, dengan menggunakan tiga macam jenis sudu turbin, Pada posisi nozzle di sudut $\mathbf{6 0}^{\circ}$ menghasilkan putaran generator dan putaran turbin paling tinggi. Posisi nozzle di sudut $\mathbf{6 0}^{\circ}$, model sudu yang disarankan untuk digunakan adalah model sudu setengah lingkaran karena pada posisi dan model sudu tersebut menghasilkan daya paling besar.
\end{abstract}

Kata Kunci-PLTMH, Effisiensi, Nozzle.

\section{PENDAHULUAN}

Wilayah Indonesia berada di daerah ber-iklim tropis hanya mengenal dua musim yaitu musim hujan dan musim kemarau. Pada saat musim hujan aliran sungai melimpah sampai mengakibatkan banjir, sebaliknya pada musim kemarau air sungai mengecil hingga sampai kering. Aliran sungai yang melimpah dimusim hujan dapat dimanfaatkan sebagai sumber energi tenaga air [1]. Dikembangkan sumber energi air sebagai upaya memenuhi pasokan listrik dari ketergantungan pembangkit listrik terhadap sumber energi seperti minyak solar, gas alam dan batubara yang hampir mencapai $75 \%$ [2].

Energi tenaga air merupakan energi yang berasal dari aliran air yang digunakan untuk memutar turbin yang dihubungkan dengan generator sehingga menghasilkan energi

\footnotetext{
${ }^{1}$ Mahasiswa Program Studi Teknik Elektro Fakultas Teknik Universitas Udayana, Jl. Beringin, No.8, Br. Pegendin, Dalung, Kuta Utara, Badung (80361) (tlp: 0361-9002171/085739172368); e-mail: daniel_kristama@yahoo.com)

${ }^{2,}$ Staf Pengajar Program Studi Teknik Elektro Fakultas Teknik Universitas Udayana, Jln, Kampus Bukit Jimbaran 80361 INDONESIA (telp: 0361-703315; fax: 0361-4321)
}

K. Daniel Kritama Vika: Studi Analisis Pengaruh Perubahan ... listrik. Untuk memutar turbin diperlukan air dalam jumlah konstan sehingga tegangan yang dihasilkan dari putaran turbin yang memutar generator juga konstan [3]. Parameter desain yang mempengaruhi Pembangkit Listrik Tenaga Mikro Hidro (PLTMH) adalah jumlah sudu, bentuk sudu, diameter turbin, rpm, lebar turbin, sudut nozzle, dan posisi nozzle [4].

Pada penelitian ini model sudu yang digunakan adalah model sudu setengah lingkaran dengan jumlah 16 sudu, model sudu sirip dan segitiga dengan jumlah 8 sudu, dengan mengatur titik jatuh air terhadap turbin. Posisi nozzle yang diteliti ada di titik sudut $0^{\circ}, 15^{\circ}, 30^{\circ}, 45^{\circ}, 60^{\circ}$, dan $75^{\circ}$. Dalam penelitan ini penulis ingin melihat apakah posisi nozzle berpengaruh pada rpm sebagai penghasil tegangan pada generator.

\section{PROTOTIPE PLTMH}

\section{A. Potensi Air}

Aliran air mempunyai energi yang dapat digunakan untuk memutar roda turbin, sehingga pusat-pusat tenaga air dibangun di sungai dan daerah pegunungan. [8]

$$
\begin{aligned}
& P=\rho \cdot Q \cdot g \cdot H \\
& \mathrm{P}=\text { Daya }(\mathrm{W}) \\
& \rho=\text { Kerapatan Air }\left(1000 \mathrm{~kg} / \mathrm{m}^{3}\right) \\
& \mathrm{Q}=\text { Debit Air }\left(\mathrm{m}^{3} / \mathrm{s}\right) \\
& g=\text { Gravitasi Bumi }\left(9,81 \mathrm{~m} / \mathrm{s}^{2}\right) \\
& \mathrm{H}=\text { Ketinggian Jatuh Air }(\mathrm{m})
\end{aligned}
$$

Setelah diperoleh daya, dapat diketahui efisiensi dari pembangkit listrik tenaga mikro hidro sebagai berikut :

$$
\eta=\frac{\text { Pout }}{\text { Pin }}
$$

Dimana :

$\eta=$ Efisiensi

$\mathrm{P}_{\mathrm{In}}=$ Daya Kincir $(\mathrm{W})$

$\mathrm{P}_{\text {Out }}=$ Daya Generator $(\mathrm{W})$

B. Macam-macam Parameter Sudu Turbin

1. Sudu Turbin Segitiga

Dalam penelitian ini jumlah sudu dirancang sebanyak 8 buah berbentuk segitiga yang melekat di tepi roda. Dalam menentukan jumlah sudu turbin tetap dipertimbangkan dari jari-jari turbin bagian luar karena jarak antara sudu dihitung berdasarkan keliling lingkaran luar dibagi dengan jumlah sudu (N) [1].

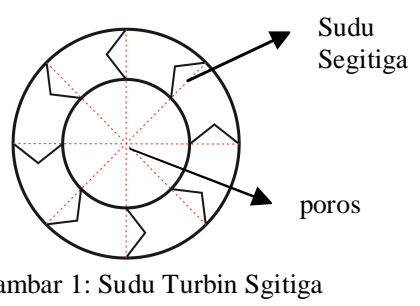

p-ISSN:1693 - 2951; e-ISSN: 2503-2372

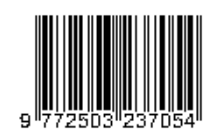




\section{Sudu Turbin Setengah Lingkaran}

Bentuk sudu dalam penelitian ini adalah bulat untuk mengarahkan pancaran air kedalam sudu. Air akan mendorong sudu pada bagian tepi roda, mengalir diatas sudu, keluar meninggalkan sudu, melewati ruang kosong pada bagian dalam roda, selanjutnya memasuki sudu di sisi bagian dalam roda, dan akhirnya keluar meninggalkan roda. Oleh karena itu, sebuah pancaran air (jet) dalam roda pada dasarnya radial, diameter roda praktis tetap dari dampak jumlah air, dan luasan roda yang diinginkan dapat disesuaikan ter volume air [1]. Sudu Setengah Lingkaran

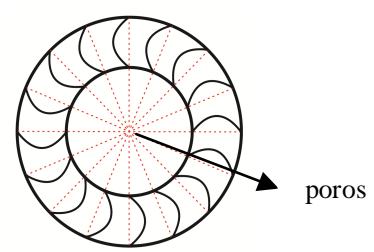

Gambar 2: Sudu Turbin Setengah Lingkaran

\section{Sudud Turbin Sirip}

Turbin sudu sirip adalah turbin air yang memiliki sudusudu berbentuk sirip yang dipasang pada bagian tepi dari pinggiran roda. Air yang mengalir melalui pipa pesat (penstock) akan mengisi sudu-sudu yang menyebabkan turbin berputar [1].

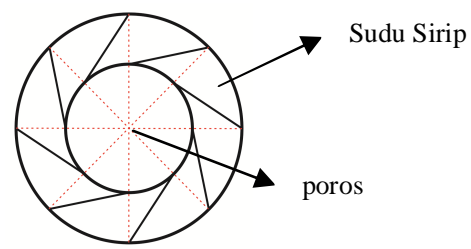

Gambar 3: Sudu Turbin Sirip

\section{Turbin Air}

Turbin air adalah turbin dengan air sebagai fluida kerja. Air yang mengalir dari tempat yang lebih tinggi menuju tempat yang lebih rendah dalam hal ini air memiliki energi potensial. Dalam proses aliran didalam pipa, energi potensial tersebut berangsur-angsur berubah menjadi energi mekanis, dimana air memutar roda turbin. Roda turbin dihubungkan dengan generator yang merubah energi mekanis (gerak) menjadi energi kinetik (listrik) [6]

\section{Daya Turbin}

Sebagaimana diketahui dari ilmu fisika, setiap benda yang ada di atas permukaan bumimempunyai energy potensial yang dirumuskan sebagai berikut:

$\mathrm{E}=$ m.g.h

Dimana E adalah energy potensial, m adalah massa, g adalah percepatan grafitasi, dan $\mathrm{h}$ adalah tinggi relative terhadap permukaan bumi.

Dari persamaan 1 dapat ditulis:

$\mathrm{dE}=\mathrm{dm} . \mathrm{g} \cdot \mathrm{h}$

dimana $\mathrm{dE}$ adalah energi yang dibangkitkan oleh elemen masa $\mathrm{dm}$ yang melalui jarak h, bilamana didefinisikan Q sebagai debit air menurut rumus berikut:

$\mathrm{Q}=\mathrm{dm} / \mathrm{dt}$
Dengan q adalah debit air, dm adalah elemen masa air dan dt adalah elemen waktu, maka dapat ditulis:

$\mathrm{P}=\mathrm{dE} / \mathrm{dt}$

$P=$ dm/dt.g.h

$\mathrm{P}=\mathrm{Q} \cdot \mathrm{g} \cdot \mathrm{h}$

Daya yang dihasilkan turbin dihitung dengan menggunakan persamaan 2 [5].

\section{E. Arah Sudu Nozzle.}

Panjang dari lengan nozzle harus lebih besar dari jari-jari roda sehingga nozzle selalu berada diluar dari roda. Sudut $\alpha$ adalah sudut yang terbentuk antara lengan nozzle dengan nozzle. Besarnya $\alpha$ di buat antara $0^{\circ}, 50,10 \mathrm{o}, 15 \mathrm{o}, 20 \mathrm{o}, 25 \mathrm{o}$, dan 30o, bertujuan untuk membandingkan besaran rpm yang dihasilkan pada setiap sudut nozzle. Pada sudut 350 dan 400 air sudah tidak mengenai sudu turbin. Range sudut $\alpha<90^{\circ}$, dengan arah ditunjukan pada sudu, seperti terlihat pada gambar 4 [4].

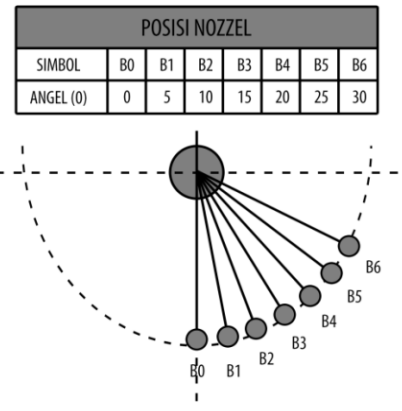

Gambar 4: Arah Sudut Nozzle

\section{F. Aliran Air}

Aliran air mempunyai energi yang dapat digunakan untuk memutar roda turbin, karena itu pusat-pusat tenaga air dibangun di sungai dan daerah pegunungan. Dengan menggunakan pipa, air tersebut dialirkan ke rumah pusat tenaga dengan tingkat kemiringan yang efektif untuk memutar turbin yang dihubungkan ke generator. Diperlukan jumlah air yang konstan untuk memutar turbin air, sehingga putaran generator juga konstan [9].

\section{G. Generator}

Generator dapat dibedakan menjadi dua macam, yaitu generator AC yang menghasilkan arus bolak balik dan Generator DC yang menghasilkan arus searah. Arus DC dan $\mathrm{AC}$ dapat digunakan untuk penerangan dan alat-alat pemanas [7].

\section{METODE PENELITIAN}

Dapat dilihat pada gambar 5:

\section{a. Studi Pustaka}

Mencari referensi-referensi atau buku tentang Pembangkit Listrik Tenaga Mikro Hidro (PLTMH). Selanjutnya mencari jurnal-jurnal dan artikel tentang kinerja turbin.

\section{b. Perancangan Prototipe}

Perancangan pada prototipe ini meliputi perancangan posisi nozzle terhadap kincir sesuai parameter. dengan menggunakan volume box 330 liter, ketinggian jatuh air 0,4 meter, panjang pipa $160 \mathrm{~cm}$, dan diameter pia 3/4 dan $1 \mathrm{dim}$, 

$10-28 \mathrm{lt} / \mathrm{min}$ atau $0,16-0,46 \mathrm{lt} / \mathrm{s}$. posisi nozzle yang akan diteliti dalam penelitian ini yaitu: posisi nozzle ada di sudut $0^{0}, 15^{0}, 30^{\circ}, 45^{\circ}, 60^{\circ}$, dan $75^{\circ}$.

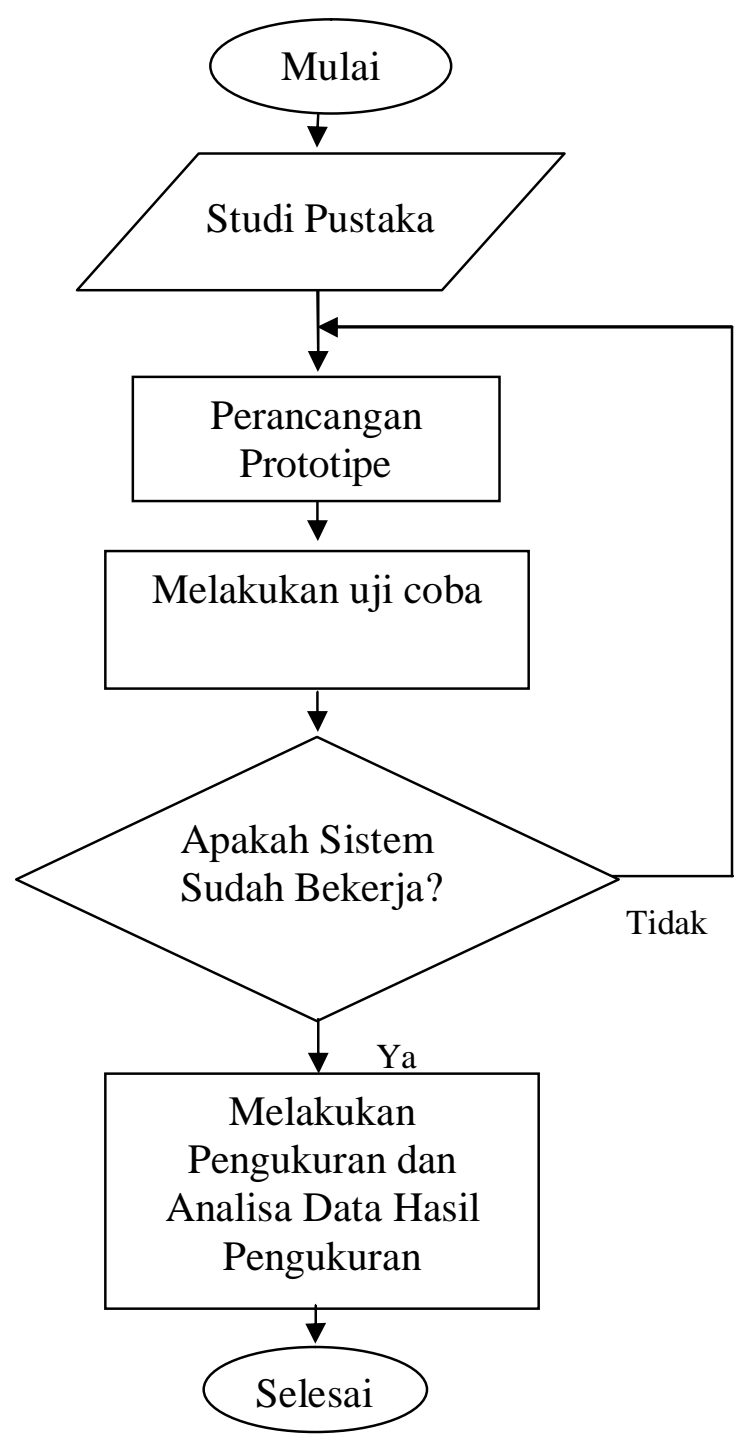

Gambar 5: Alur Penelitian

\section{c. Melakukan Uji Coba}

Melakukan uji coba terhadap hasil desain dari perubahan posisi nozzle dan model sudu

\section{d. Pengukuran dan Analisa Data Hasil Pengukuran.}

Pengukuran pada penelitian ini dengan cara merubah posisi nozzle atau jatuhnya air, yaitu ada di $\angle 0^{\circ}, \angle 15^{\circ}, \angle 30^{\circ}$, $\angle 45^{\circ}, \angle 60^{\circ}$, dan $\angle 75^{\circ}$ untuk pengambilan data dari ketiga jenis turbin. Parameter yang akan diukur meliputi: debit air, tekanan air, Putaran turbin, putaran generator, tegangan, arus, daya generator, dan efisiensi. Untuk mengukur tegangan, arus, dan daya output dilakukan pengukuran tanpa beban dan dengan beban 3,6 watt.

K. Daniel Kritama Vika: Studi Analisis Pengaruh Perubahan ...

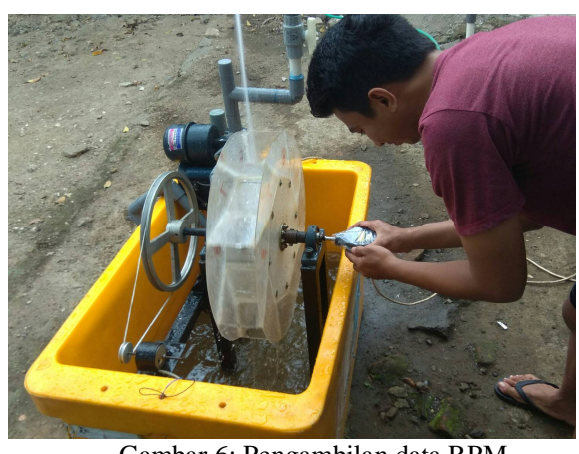

Dapat dilihat pada gambar diatas pengambilan data RPM pada kincir dengan menggunakan alat ukut tachometer, pengambilan data ini dilakukan secara berulang sesuai dengan parameter penelitian yang diteliti.

\section{HASIL DAN PEMBAHASAN.}

\section{A. DESAIN POSISI NOZZLE}

Posisi nozzle pada pemodelan pembangkit listrik tenaga mikro hidro ini sangat berpengaruh terhadap nilai dari parameter-parameter yang diukur. Berikut adalah gambaran posisi nozzle terhadap jatuhnya air ke kincir.

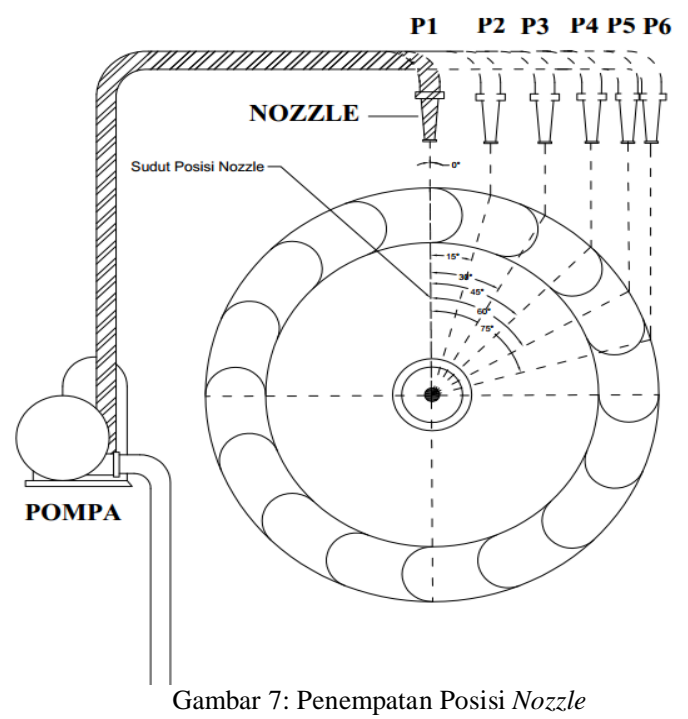

1. Posisi nozzle di P1 $\left(0^{0}\right)$.

Pada posisi nozzle di $\angle 0^{0}$ posisi jatuhnya air tegak lurus mengenai kincir. Pada posisi ini air harus memenuhi sudu kincir agar dapat berputar, sehingga putaran kincir tidak konstan.

2. Posisi nozzle di P2 $\left(15^{0}\right)$.

Pada posisi nozzle di $15^{\circ}$ posisi jatuhnya air ada di $\angle 15^{\circ}$ mengenai kincir, tegak lurus terhadap sumbu x. Pada sudut ini jatuhnya air sudah mengenai daerah aktif berputar pada kincir, sehingga sudah dapat memutar kincir secara konstan.

3. Posisi nozzle di P3 $\left(30^{\circ}\right)$.

Pada posisi nozzle di $30^{\circ}$ posisi jatuhnya air ada di $\angle 30^{\circ}$ mengenai kincir, tegak lurus terhadap sumbu x. Pada sudut ini jatuhnya air sudah mengenai daerah aktif berputar pada kincir, sehingga sudah dapat memutar kincir secara konstan

p-ISSN:1693 - 2951; e-ISSN: 2503-2372

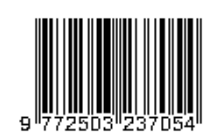


4. Posisi nozzle di P4 $\left(45^{\circ}\right)$.

Pada posisi nozzle di $45^{\circ}$ posisi jatuhnya air ada di $\angle 45^{\circ}$ mengenai kincir, tegak lurus terhadap sumbu x. Pada sudut ini jatuhnya air sudah mengenai daerah aktif berputar pada kincir, sehingga sudah dapat memutar kincir secara konstan.

5. Posisi nozzle di P5 $\left(60^{\circ}\right)$.

Pada posisi nozzle di $60^{\circ}$ posisi jatuhnya air ada di $\angle 60^{\circ}$ mengenai kincir, tegak lurus terhadap sumbu x. Pada sudut ini jatuhnya air sudah mengenai daerah paling aktif berputar pada kincir, sehingga pada sudut ini kincir memiliki kecepatan putaran paling tinggi.

6. Posisi nozzle di P6 $\left(75^{\circ}\right)$.

Pada posisi nozzle di $75^{\circ}$ posisi jatuhnya air ada di $\angle 75^{\circ}$ mengenai kincir, tegak lurus terhadap sumbu x. Pada sudut ini jatuhnya air sudah mengenai daerah kurang aktif berputar pada kincir, sehingga kecepatan putar kincir lebih rendah dari posisi nozzle di $\angle 45^{\circ}$ dan $\angle 60^{\circ}$.

\section{B. Pengukuran Debit Air}

Debit air adalah besaran yang menyatakan banyaknya air yang mengalir selama satu detik yang melewati satu penampang luas. Volume bejana yang digunakan pada penelitian ini sebesar 1 liter atau $0,001 \mathrm{~m}^{3}$ dengan waktu yang diperlukan untuk memenuhi bejana yaitu 10 detik. Sehingga didapat:

$$
\begin{aligned}
& \text { Debit }=\frac{0,001}{10} \\
& \text { Debit }=0,0001 \mathrm{~m}^{3} / \mathrm{s}
\end{aligned}
$$

Setelah diperoleh besarnya debit maka dapat ditentukan besarnya daya output turbin yang dihasilkan, yaitu:

$$
\begin{aligned}
\mathrm{P} & =1000 \cdot 0,0001 \cdot 9,81 \cdot 0,4 \\
& =0,4 \text { Watt }
\end{aligned}
$$

\section{Posisi Nozzle Terhadap Daya Output Generator}

Dari pengukuran yang telah dilakukan pada ketiga jenis sudu turbin sesuai dengan parameter pengukuran pembangkit listrik tenaga mikro hidro, dengan mengalikan tegangan dan arus yang didapat pada saat pengukuran sehingga menghasilkan daya output generator dapat dilihat pada grafik dibawah ini,

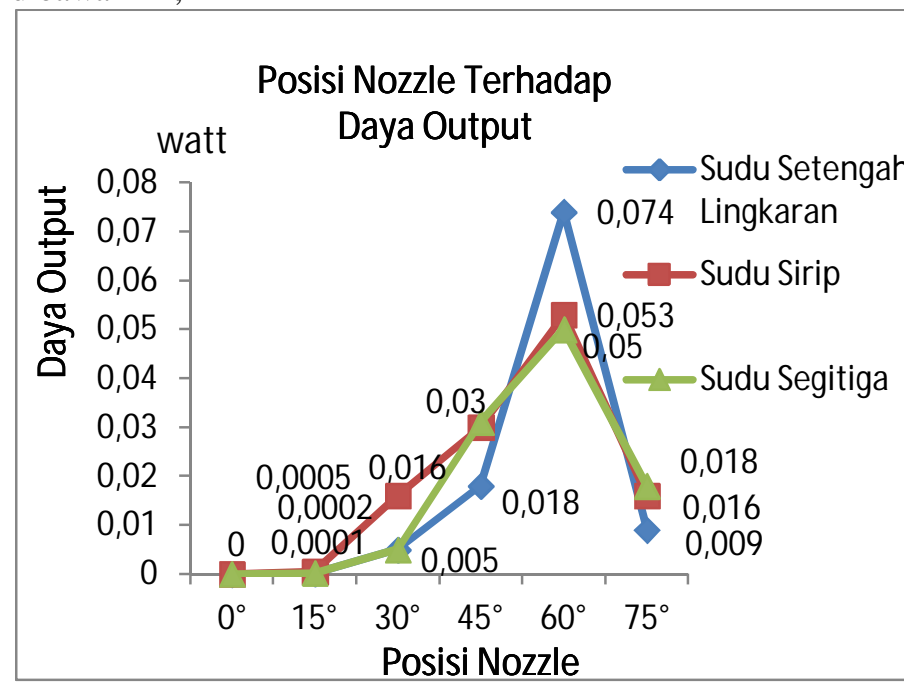

Gambar 8: Daya Output Generator
Dari data diatas, peneliti tidak melakukan pengukuran pada posisi nozzle di sudut $0^{0}$ dan $15^{\circ}$. Hal tersebut disebabkan pada posisi nozzle di sudut $0^{\circ}$ dan $15^{\circ}$ turbin tidak berputar. Daya output generator paling besar dari masing-masing turbin terletak pada sudut $60^{\circ}$. Sedangkan pada posisi nozzle di sudut $75^{\circ}$ air yang jatuh dari nozzle tidak seluruhnya mengenai sudu turbin sehingga putaran turbin dan daya yang dihasilkan menjadi berkurang. Pada sudut $90^{\circ}$, air yang jatuh dari nozzle hanya sedikit yang mengenai turbin, sehingga tidak ada putaran yang dihasilkan.

\section{Posisi Nozzle Terhadap Efisiensi}

Dari perhitungan yang telah dilakukan pada ketiga jenis sudu turbin sesuai dengan parameter pembangkit listrik tenaga mikro hidro, dengan membagi daya output turbin dengan daya outpun generator yang didapat pada saat melakukan perhitungan, maka dapat dilihat pada Gambar 4.3 di bawah ini

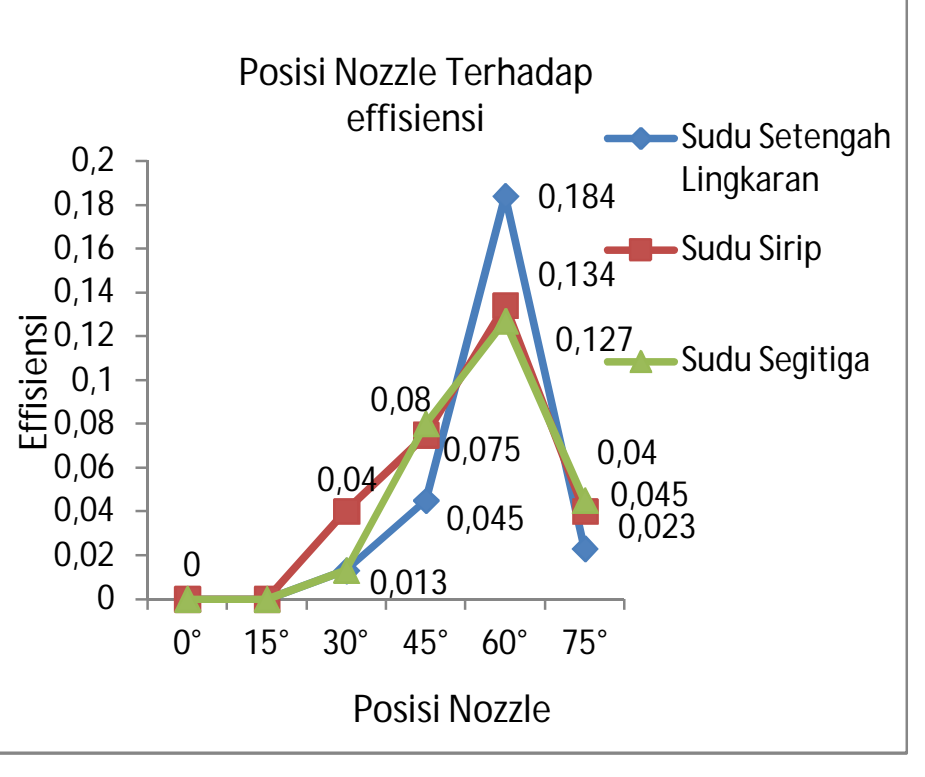

Gambar 9: Grafik Effisiensi

Dari perhitungan yang telah dilakukan, diperoleh efisiensi terbesar pada posisi nozzel di sudut $60^{\circ}$ dengan model sudu setengah lingkaran yaitu sebesar 0,184 , sedangkan efisiensi terendah diperoleh pada posisi nozzel di sudut $30^{\circ}$ yaitu 0,013 . Sementara pada posisi nozzel di sudut $75^{\circ}$ terjadi penurunan efisiensi, hal tersebut dikarenakan daya output pada sudut nozzle $75^{\circ}$ menurun sehingga berpengaruh terhadap efisiensi. Untuk sudut nozzle $0^{\circ}, 15^{\circ}$ dan $90^{\circ}$ efisiensi tidak dihitung karena pada sudut nozzle tersebut kincir dianggap tidak berputar, sehingga generator tidak menghasilkan daya output. Dari data pada tabel 4.15 dapat diketahui bahwa efisiensi cenderung meningkat bersamaan dengan meningkatnya posisi nozzel. Namun untuk posisi nozzel di sudut $75^{\circ}$ karena kecepatan putaran kincir menurun yang disebabkan oleh air sudah tidak lagi mengenai daerah paling aktif pada kincir, maka efisiensi pada posisi nozzel di sudut $75^{\circ}$ ikut menurun. Begitu juga pada posisi nozzel di sudut $90^{\circ}$, karena pada sudut nozzle tersebut kincir dianggap tidak berputar dan generator tidak menghasilkan daya output, maka tidak dilakukan perhitungan efisiensi. Dari hasil efisiensi yang telah dihitung dapat diperoleh persentase efisiensi pemodelan pembangkit 
listrik tenaga mikro hidro tertinggi pada posisi nozzle di sudut $60^{\circ}$.

Efisiensi pada pemodelan PLTMH ini diperoleh dari hasil bagi daya output dengan daya input. Daya output tertinggi pemodelan ini adalah 0,153 watt pada sudut nozzle $30^{\circ}$, sedangkan daya input adalah 0,6 watt, sehingga efisiensi pemodelan PLTMH ini adalah :

$$
\begin{aligned}
\eta & =\frac{\text { Pout }}{\text { Pin }} \\
& =\frac{0,074}{0,4} \\
& =0,18
\end{aligned}
$$

Jadi efisiensi pemodelan PLTMH ini adalah 0,18 atau 18\%. Efisiensi dari pemodelan pembangkit listrik tenaga mikro hidro ini masih kurang tinggi dikarenakan daya output yang dihasilkan oleh generator masih relatif kecil.

\section{KESIMPULAN.}

Simpulan penelitian ini adalah telah dibangun perancangan pada prototipe pembangkit listrik tenaga mikro hidro dengan merancang posisi nozzle sehingga didapat titik jatuh air di sudut $\mathrm{P} 1=0^{0,} \mathrm{P} 2=15^{\circ}, \mathrm{P} 3=30^{\circ}, \mathrm{P} 4=45^{\circ}, \mathrm{P} 5=60^{0}$, dan $\mathrm{P} 6=75^{\circ}$, dimana efisiensi tertinggi didapat pada posisi nozzle di sudut $60^{\circ}$ sebesar $18 \%$ pada model sudu setengah lingkaran.

\section{REFERENSI}

[1] L. Jasa. "Investigasi sudut Nozzle dan sudut kelengkungan sudu turbin air untuk meningkatkan efisiensi mikro hidro". Surabaya: ITS.2015.

[2] M. T. H. Kristiati. Sumber Energi Penghasil Listrik. Cetakan Pertama Citra Aji Parama. Yogyakarta. 2011.

[3] A. Indriani 'Rancang Bangun dan Pembuatan Mode Sistem Pembangkit Listrik Tenaga Mikro Hidro Dengan Metode Elemen Hingga Berdasarkan Posisi dan Bentuk Sudu Srew Pump”. Bengkulu: Universitas Bengkulu. 2013.

[4] A. I. Weking, L. Jasa, Y. P. Sudarmojo 'Modul Simulasi Kontrol Hidro Power Untuk Praktikum Mahasiswa Teknik Elektro'. Badung : Universitas udayana. 2015.

[5] Jasa L., Ardana I P., Priyadi, A., Purnomo, M.H. 2016., 'Strategi Memanfaatkan Energi Murah dan Ramah Lingkungan'. Yogyakarta: Teknosain

[6] Putro, Y.S.S., Juwono, P.T., Wicaksosno,P.H.2014., 'Studi Peraencanaan PLTMH di Sungai Atei Desa Tumbang Atei'. Malang: Universitas Brawijaya.

[7] P A. Hendarto."Pemanfaatan pemandian umum untuk pembangkit listrik tenaga mikrohidro (PLTMh) menggunakan kincir tipe overshot". Surakarta : Universitas Muhammadiyah Surakarta. 2012.

[8] F H. Sholihah."Rancang bangun prototipe pembangkit listrik tenaga mikrohidro (PLTMH)". Surabaya : PENS-ITS. 2012

[9] Jasa, L., "Mengatasi Krisis Energi Dengan Memanfaatkan Aliran Pangkung Sebagai Sumber Pembangkit Listrik Alternatif". Bali: Universitas Udayana. 2010. 
Halaman ini sengaja dikosongkan ] 